hydrocarbons such as benzene, naphthalene, and anthracene, which are separated by fractional distillation, leaving pitch as residue. The red-hot coke which remains after the gas has been driven off is emptied from the retorts and quenched.

It is not surprising that in the past cases of industrial injury and disease should have been common in an industry where so many hazardous substances are encountered. Many cases of gassing by carbon monoxide and some by hydrogen sulphide have been reported ${ }^{1}$ but these are now unusual. Exposure to tar or pitch can produce an acute erythema of the skin sometimes accompanied by conjunctivitis. Some exposed workers develop acne or a chronic dermatosis which can take a variety of forms. Continued exposure may give rise to tar warts, which may gradually regress or may become malignant, sometimes many years after exposure has ceased. ${ }^{2}$ The special risk of cancer of the skin and scrotum in gas workers has been known for many years. Between 1920 and 1943,259 cases of epithelioma of the skin, of which $32 \%$ were scrotal, were notified in "coal gas makers." 3 At a recent inquest in London a verdict of accidental death was returned on a 62-year-old man who had worked in gasworks for 47 years and had developed an epithelioma of his scrotum. ${ }^{4}$ That there may be an increased incidence of carcinoma of the lung in gas workers was first suggested in $1936^{56}$ and confirmed by a number of workers subsequently. ${ }^{7-9}$ It was considered as long ago as $1931^{10}$ that there might be an added risk of cancer of the bladder in these men.

R. Doll and the senior medical officers of several gas boards have now reported the results of a study on the mortality of selected groups of gas workers who have been observed over an eight-year period. ${ }^{11}$ They found that the annual death rate was higher in the retort-house workers, who had had prolonged exposure to the products of coal carbonization, than in gas workers who had not been exposed. The death rate of a group of workers having intermittent exposure fell between the two. The increase in mortality of the retorthouse workers compared with the unexposed gas workers, which was not large, was due mainly to cancer of the lung (69\% increase) and to chronic bronchitis (126\% increase). The mortality from cancer of the bladder was also slightly greater in the heavily exposed group, though the total number of cases seen was small. In addition, a small number of deaths was attributed to pneumoconiosis in bricklayers exposed to siliceous dust while repairing retorts, and one retort-house worker died from carcinoma of the scrotum. Though not statistically significant, there were more deaths from lung cancer and fewer deaths from chronic bronchitis among the

\footnotetext{
${ }^{1}$ Legge, T., Industrial Maladies, edited by S. A. Henry, 1934, Oxford University Press, London.

2 Fisher, R. B. W., Trans. Ass. industr. med. Offrs., 1954, 3, 315

Henry, S. A., Cancer of the Scrotum in Relation to Occupation, 1946 Oxford University Press, London.

- Gaardian, 25 March, p. 5.

- Kennaway, N. M., and Kennaway, E. L., F. Hyg. (Lond.), 1936, 36, 236.

- Kuroda, S., and Kawahata, K., Z. Krebsforsch., 1936, 45, 36.

Doll, R., Brit. Y industr. Med., 1952, 9, 180

${ }^{8}$ Sutherland, R. B., cited by Doll, R., in Brit. F. industr. Med., 1959, 16,

Christian, H. A., F. occup. Med., 1962, 4, 133.

1931, S. A., Kennaway, E. L., and Kennaway, N. M., f. Hyg. (Lond.), $1931,31,125$.

' Doll, R., Fisher, R. B. W., Gammon, E. J., Gunn, W., Hughes, G. O., Tyrer, F. H., and Wilson, W., Brit. F. industr. Med., 1965, 22, 1.

12 Cook, J. W., Hieger, I., Kennaway, E. L., and Mayneord, W. V., Proc. roy. Soc. B., 1932, 111, 455.

13 Hewett, C. L., and Hieger, I., F. chem. Soc., 1933, p. 395.

14 Lawther, P. J., Commins, B. T., and Waller, R. E., Brit. Y. industr. Med.,

Brit. med. Э., 1965, 1, 329.
}

men working in horizontal retort houses than in vertical retort houses. Taking all the available evidence together, Doll and his colleagues concluded that "exposure to products of coal carbonization can give rise to cancer of the lung and to bronchitis, and probably also to cancer of the bladder."

The classical work which led to the isolation and identification of 3:4-benzpyrene as a potent carcinogen was performed on pitch obtained from a gasworks. ${ }^{12}{ }^{13}$ In a complementary study to that of Doll and his colleagues, P. J. Lawther and his co-workers found large amounts of this carcinogen and of other polycyclic hydrocarbons in the tarry fumes escaping from the retorts. ${ }^{14}$ The men working in the retort houses were exposed to a mean concentration of 3:4-benzpyrene that was over 100 times the average concentration found in the air in the City of London. Above the horizontal retorts in an old retort house, now demolished, the concentration of this carcinogen was 10,000 times that found in the City, and the "topman" working there was likely to have been exposed to this concentration in the course of his duties. So far the data have been insufficient to show whether there is any further excess of mortality among the small number of men working in the most polluted areas.

$\beta$-naphthylamine, which is known to give rise to cancer of the bladder, ${ }^{15}$ has been detected in the fumes inside a retort house, ${ }^{11}$ and this and possibly other carcinogenic aromatic amines may be responsible for the slightly greater mortality from the disease that has also been reported. The increased mortality of retort-house workers from chronic bronchitis is at present difficult to explain. Exposure to sulphur dioxide was suspected, but little excess was found in the one retort house where its concentration was measured. ${ }^{14}$

Environmental factors, some of which are occupational, sometimes play an important part in the aetiology of disease. Epidemiological techniques are of great value in the elucidation of these factors, and this has been well illustrated in this recent study of gas workers.

\section{Subcutaneous Rheumatoid Nodules}

About $20 \%$ of adult patients with rheumatoid arthritis develop palpable subcutaneous nodules, usually on the ulnar border of the forearm, less frequently at other sites subject to pressure such as the heel. Once formed they are apt to persist for a long time. They are almost invariably associated with positive tests for rheumatoid serum factor, ${ }^{1}$ and in general indicate that the disease will take a rather unfavourable course. They consist of fibrous tissue of varying maturity, in which are scattered about the characteristic necrotic, so-called fibrinoid foci, whose serpiginous outlines tend to be delineated by a palisade of cells, mainly fibroblasts. Within the necrotic foci are thin reticulin fibres (like those formed in granulation tissue), much amorphous material, and some nuclear debris. Lymphocytes and plasma cells are usually evident, particularly round blood-vessels in the peripheral parts of the nodule. This subcutaneous lesion apparently occurs in no other disease except granuloma annulare.

The subcutaneous nodule of rheumatic fever, and that of Still's disease, which resembles it, share many of the features of the rheumatoid nodule but can usually be distinguished histologically. ${ }^{2}$ Subcutaneous nodules virtually identical with 
those of rheumatoid arthritis are occasionally encountered in apparently healthy people; in adults they may presage the onset of sero-positive arthritis, but in children the prognosis is good and rheumatic disease is not likely to supervene. ${ }^{34}$

It has been suggested on morphological grounds that the fibrinoid areas are due to swelling or coagulation of the ground substance of fibrous tissue with subsequent infiltration by fibrinous exudate. ${ }^{56}$ Other investigators have described swelling of collagen fibres or suggested that the essential defect is a precipitation of the acidic mucopolysaccharides of the connective tissue. ${ }^{7}$ The necrotic foci contain tyrosine and polysaccharides (as judged by periodic acid Schiff staining) but reactions for acidic polysaccharides are weak or absent. ${ }^{8}$ Since fibrinous exudates also give these and other staining reactions some observers have concluded that the fibrinoid is really nothing more mysterious than a deposit of fibrin in inflamed connective tissue. ${ }^{9}$ In an attempt to find out more about the composition of the nodule J. $\mathrm{H}$. Kellgren and his colleagues ${ }^{10}$ examined parts of it with the electron-microscope and by $x$-ray diffraction. They found no fibrin. The necrotic foci differed from the surrounding fibrous tissue in containing fewer, but structurally normal, collagen fibrils, and much more amorphous material which did not appear to be collagen protein. The non-collagenous nature of the amorphous moiety was apparently confirmed biochemically, ${ }^{11}$ so it seems unlikely that the lesion follows the precipitation of some collagen precursor.

In a more recent study of the ultrastructure of the rheumatoid nodule W. Cochrane and colleagues ${ }^{12}$ also found that the collagen present has a normal appearance and is neither swollen nor fragmented. They further showed that the necrotic foci contain an abundance of cellular remnants (indicating that the areas have at one time been highly cellular) and much granular and filamentous material. The filaments could not be positively identified as fibrin. However, both the staining properties ${ }^{13}$ and the ultrastructure of fibrin probably depend on the conditions in which it is formed and possibly on its age, so that its certain identification can present technical difficulties. There are in fact few observations on the early stages of the lesion. L. Sokoloff and colleagues $^{14}$ found that the nodule is heralded by oedema of connective tissue and growth of granulation tissue, and that the fibrinoid develops in relation to blood-vessels. That fibrinoid foci indistinguishable from those in the subcutaneous nodule can arise in pre-existing granulation tissue seems certain from Kellgren and J. Ball's studies of the tendon lesions in rheumatoid arthritis. ${ }^{15}$ Focal necrosis in granulation tissue-one cause of which might be pressure trauma -could account for the observed changes in the established nodule.

\footnotetext{
1 Kellgren, J. H., and Ball, J., Brit. med. F., 1959, 1, 523.

Bywaters, E. G. L., Glynn, L. E., and Z̈eldis, A., Ann. rheum. Dis., 1958, 17, 278.

1958, 17, 278. Lowney, E. D., and Simons, H. M., Arch. Dermatol., 1963, 88, 853.

Beatty, E. C., Arch. Path., 1959, 68, 154.

Klinge, F., Erg. Path., 1933, 27, 1.

- Bahrmann, E., Virch.' Arch., 1937, 300, 342.

'Altshuler, C. H., and Angevine, D. M., Amer. F. Path., 1949, 25, 1061.

- Montgomery, P. O'B., and Muirhead, E. E., ibid., 1957 33, 285.

- Movat, H. Z., and More, R. H., Amer. F. clin. Path., 1957, 28, 331.

10 Kellgren, J. H., Ball, J., Astbury, W. T., Reed, R., and Beighton, E., Nature (Lond.), 1951, 168, 493.

11 Ziff, M., Kantor, T., Bien, E., and Smith, A., F. clin. Invest., 1953, 32, 1253.

12 Cochrane, W., Davies, D. V., Dorling, J., and Bywaters, E. G. L., Ann. rheum. Dis., 1964, 23, 345.

1s Gitlin, D., and Craig, J. M., Amer. F. Path., 1957, 33, 267.

11 Sokoloff, L., McCluskey, R. T., and Bunim, J. J., Bull. N.Y. Acad. Med., 1953, 29, 733.

${ }^{15}$ Kellgren, J. H., and Ball, J., Ann. rheum. Dis., 1950, 9, 48
}

Clearly there are many gaps and uncertainties in our knowledge of the nodule. Future studies by both traditional and more sophisticated methods of tissue analysis might with profit pay particular attention to the early stages of its development.

\section{Treatment of Depression}

The most powerful treatments of depressive illness now available are electric convulsion therapy (E.C.T.) and the two groups of antidepressant drugs, imipramine (Tofranil) and its analogues and the monoamine oxidase inhibitors. The value of E.C.T. in depressive illness, particularly when given during the period of mental involution characteristic of the second half of life, is firmly established, but in spite of many trials there is still disagreement about the efficacy of antidepressant drugs and the specific indications for prescribing any one of them. This is partly due to problems of psychiatric terminology and partly to inadequacies in the design and reporting of drug trials, so that all too often it is impossible to make a valid comparison of one group of patients with another.

The Medical Research Council's Clinical Psychiatry Committee has now completed a six months' trial on 250 patients, and its report appears at page 881 of the B.M.F. this week. It was designed to compare the merits of imipramine and a monoamine oxidase inhibitor, phenelzine (Nardil), in the treatment of depressive illness, and to compare the effects of these drugs with those of E.C.T. and a placebo. In view of the difficulties of carrying out a trial of this nature and scope, both the design and the way in which it has been executed and reported upon deserve the highest praise. Patients spent the first four weeks in hospital, but subsequently became out-patients unless there were clinical contraindications. Each patient was allocated randomly to treatment for a minimum period of four weeks by imipramine, phenelzine, E.C.T., or placebo. If at the end of this period the response was poor, treatment could be changed.

About one-third of the patients recovered on the placebo alone, a figure which probably reflects the effects of sociopsychological factors together with the tendency of depressive illness to improve spontaneously. Treatment either with imipramine or with E.C.T. increased this recovery rate considerably, but phenelzine appeared to be no more effective than the placebo. At this point it is important to recognize that the majority of patients included in the trial probably had a severe endogenous type of depressive illness. All were aged between 40 and 69 years and in addition to feeling and looking depressed showed one or more of the following symptoms: self-depreciation with a morbid sense (or delusional ideas) of guilt; sleep disturbance; hypochondriasis; retardation of thought and action; agitated behaviour. Many psychiatrists believe that imipramine is most effective in the treatment of endogenous depressions, while monoamine oxidase inhibitors such as phenelzine are more useful in exogenous or reactive depression, particularly when anxiety is prominent. ${ }^{1}$ It is not surprising, therefore, if this is so, to find that phenelzine in this trial is no more effective than a placebo. If exogenous or reactive depression

\footnotetext{
Brit. med. 7., 1964, 2, 522.

Ibid., 1964, i, 770.
} 